Article

\title{
Seedling Growth and Transcriptional Responses to Salt Shock and Stress in Medicago sativa L., Medicago arborea L., and Their Hybrid (Alborea)
}

\author{
Eleni Tani ${ }^{1}$, Efi Sarri ${ }^{1}$, Maria Goufa ${ }^{1}$, Georgia Asimakopoulou ${ }^{1}$, Maria Psychogiou ${ }^{2}$, \\ Edwin Bingham ${ }^{3}$, George N. Skaracis ${ }^{1}$ and Eleni M. Abraham ${ }^{4, *(D)}$
}

1 Department of Crop Science, Laboratory of Plant Breeding and Biometry, Agricultural University of Athens, Iera Odos 75, 11855 Athens, Greece; etani@aua.gr (E.T.); efisarri.18@gmail.com (E.S.); marog@aua.gr (M.G.); georgia_asim@hotmail.com (G.A.); gskaracis@aua.gr (G.N.S.)

2 Department of Natural Resources Management and Agricultural Engineering, Laboratory of Agricultural Hydraulics, Agricultural University of Athens, Iera Odos 75, 11855 Athens, Greece; mariapsy1@gmail.com

3 Agronomy Department, University of Wisconsin-Madison, Madison, WI 53706, USA; ebingham@wisc.edu

4 Faculty of Agriculture, Forestry and Natural Environment, School of Forestry and Natural Environment, Aristotle University of Thessaloniki, 54124 Thessaloniki, Greece

* Correspondence: eabraham@for.auth.gr; Tel.: +30-231-099-2301

Received: 16 September 2018; Accepted: 15 October 2018; Published: 18 October 2018

\begin{abstract}
Salinity is a major limiting factor in crop productivity worldwide. Medicago sativa L. is an important fodder crop, broadly cultivated in different environments, and it is moderately tolerant of salinity. Medicago arborea L. is considered a stress-tolerant species and could be an important genetic resource for the improvement of $M$. sativa's salt tolerance. The aim of the study was to evaluate the seedling response of $M$. sativa, M. arborea, and their hybrid (Alborea) to salt shock and salt stress treatments. Salt treatments were applied as follows: salt stress treatment at low dose $(50 \mathrm{mM} \mathrm{NaCl})$, gradual acclimatization at 50-100 and 50-100-150 mM NaCl, and two salt shock treatments at 100 and $150 \mathrm{mM} \mathrm{NaCl}$. Growth rates were evaluated in addition to transcriptional profiles of representative genes that control salt uptake and transport (NHX1 and RCI2A), have an osmotic function (P5CS1), and participate in signaling pathways and control cell growth and leaf function (SIMKK, ZFN, and $A P 2 / E R E B$ ). Results showed that the studied population of $M$. sativa and $M$. arborea performed equally well under salt stress, whereas that of $M$. sativa performed better under salt shock. The productivity of the studied population of Alborea exceeded that of its parents under normal conditions. Nevertheless, Alborea was extremely sensitive to all initial salt treatments except the low dose (50 $\mathrm{mM} \mathrm{NaCl})$. In addition, significantly higher expression levels of all the studied genes were observed in the population of $M$. arborea under both salt shock and salt stress. On the other hand, in the population of $M$. sativa, NHX1, P5CS1, and AP2/EREB were highly upregulated under salt shock but to a lesser extent under salt stress. Thus, the populations of $M$. sativa and $M$. arborea appear to regulate different components of salt tolerance mechanisms. Knowledge of the different parental mechanisms of salt tolerance could be important when incorporating both mechanisms in Alborea populations.
\end{abstract}

Keywords: Medicago; salinity tolerance; gene expression profile; salt acclimatization

\section{Introduction}

Soil salinity is a major limiting factor in crop productivity in irrigated and non-irrigated areas worldwide [1]. It can be caused by natural processes defined as "primary salinity" and/or by human activities ("secondary salinity") that are mainly due to improper irrigation [2]. The phenomenon of salinization is growing fast in arid and semi-arid areas [3] as a result of the relatively high temperatures 
and inadequate rainfall that contribute to the accumulation of salts [4]. In this respect, climate change, which is likely to increase temperatures and to affect precipitation will probably increase salinization. From the management point of view, the utilization of salty soils could be enhanced by cultivating crops adapted to salinity.

The exposure of plants to high concentrations of sodium $\left(\mathrm{Na}^{+}\right)$and chloride ions in soil [5] causes salt stress. In experiments, it occurs in one of two forms: (a) when plants are subjected to gradual application of $\mathrm{NaCl}$ until a final, prearranged salt concentration is reached, and (b) when plants are exposed to low levels of salinity [6,7]. Salt stress has two main components: a hyperosmotic stress caused by the reduction of water potential, and a hyper-ionic stress resulting from the accumulation of ions to a toxic level for plant growth [8]. Osmotic stress happens instantly when roots come into contact with solutions containing high concentrations of salts, and ionic stress follows the osmotic response.

On the other hand, salt shock is an extreme form of salt stress, where plants are abruptly subjected to high concentrations of $\mathrm{NaCl}$. The main component of the salt shock is the hyperosmotic stress $[9,10]$ due to large differences in osmotic pressure between solutes outside the cell cytoplasm, and solutes inside the cell cytoplasm. Cell plasmolysis and leakage of osmolytes occur under osmotic stress, phenomena that do not appear under ionic stress, indicating that gene expression is different in response to salt stress and salt shock [10].

According to Reference [11], genes that contribute to salt tolerance in plants can be categorized into three functional groups: (1) those that regulate the salt uptake and transport, (2) those with osmotic function, and (3) those that regulate plant growth under saline soil. The latter genes are related to transcription factors and signal transduction proteins. In this regard, the most responsive genes in salt stress experiments were related to transcription and signaling pathways and/or to ion transport, and are expected to be responsive to ionic changes [12-14]. On the other hand, the expression of genes with osmotic function alters rapidly under salt shock, while ionic-responsive genes change to a lesser extent.

The majority of molecular and biochemical research is focused on experiments that are typically performed using high $\mathrm{NaCl}$ doses $[10,11]$ although salt shock rarely occurs in nature. This is due to the fact that $\mathrm{NaCl}$ concentration rises gradually, either via increasing water levels or by the slow drying of the soil profile due to evaporation and plant uptake. However, imposition of salt stress through gradual application of $\mathrm{NaCl}$ rather than a single application of a high concentration of $\mathrm{NaCl}$ (salt shock) is preferred for studies regarding salinity tolerance, because this resembles the occurrence of salinity in nature. A comparison of gene expression in parallel experiments using gradual and sudden salt application is the most recommended method to distinguish between plant responses that are specific to salt shock and salt stress [10].

Alfalfa or Medicago sativa L. (M. sativa) is one of the most important forage legumes for improving soil composition and providing plentiful forage for animals. Even though alfalfa is a moderately salt-tolerant species and less sensitive than other legumes [15], its production and growth rate decreases when soil salt content is between 50 and $200 \mathrm{mM} \mathrm{NaCl}$ [16,17]. It is notable that salinity slightly increases the nutritive value of alfalfa [18]. The need to produce legumes with increased salt tolerance and high yield is extensively emphasized given that legumes are second in importance to agriculture and provide $33 \%$ of human nitrogen needs [19].

Several studies investigated mainly the physiological and, to a lesser extent, the molecular mechanisms associated with tolerance of $M$. sativa to salt stress/shock [20-23]. Medicago arborea $\mathrm{L}$. (M. arborea), which is considered the oldest in the genus, is known to be a tolerant species to salt stresses [24-26]. However, there is limited research on the molecular mechanisms related to its salt tolerance. Hybrids between M. sativa and M. arborea were produced in the United States of America (USA) and Australia, and are named Alborea, a high-yielding hybrid $[27,28]$. There is evidence that the high-yielding hybrids in some cases are more sensitive to stresses compared to their parents [29]. The aim of the present work was to study the seedling responses of M. sativa, M. arborea, and their hybrid in terms of transcriptional responses of selected genes under both salt stress and salt shock. The genes were selected based on the aforementioned groups that were proposed by Reference [11]. 
In particular, RCI2A and NHX1 represent genes encoding ion transporters. Their association with both salt shock and salt stress was reported for several plant species including Medicago [30-33]. P5CS1 controls the de novo synthesis of proline. Several studies associate proline accumulation with plant adaptability to salt stress [34,35]. Finally, AP2/EREB, SIMKK, and ZFN were selected from the group of transcription factors and signal transduction proteins. Their importance in the response of plants to both salt stress and salt shock was highlighted in several reports $[12,36,37]$. The following questions were addressed: (1) Is there any differentiation in the response of $M$. sativa and $M$. arborea under salt stress and salt shock? (2) What is the response of the hybrid compared to the parental species? (3) Is there any differentiation in the expression of the selected genes under salt stress and salt shock? The results of the present work can be utilized in future Alborea breeding programs.

\section{Materials and Methods}

\subsection{Plant Material}

The M. arborea parents used to develop Alborea were originally collected from Greece. The M. sativa parent population used in this study was a hybrid of the two $M$. sativa parents. Two M. sativa parents were used in crosses of M. sativa $\times$ M. arborea to produce 27 initial Alborea hybrids [27]. The Alborea population used in this study was developed from intercrosses of 20 initial hybrids using methods described by Reference [28]. Seeds were obtained from E. Bingham, Agronomy Department, Univ. Wisconsin-Madison, USA.

\subsection{Seed Pretreatment}

Seeds of M. sativa, M. arborea, and Alborea were scarified with absolute sulfuric acid for $10 \mathrm{~min}$ and then rinsed thoroughly with sterile distilled water. Bleach solution (3\%) was added for 1.5-2 min and then rinsed thoroughly. The scarified seeds were placed on petri dishes containing $0.5 \%$ agar at $4{ }^{\circ} \mathrm{C}$ overnight, and then transferred to $20^{\circ} \mathrm{C}$ (dark) for 3-4 days.

\subsection{Growth Conditions and Salt Stress Treatments}

Seedlings with about $1-\mathrm{cm}$-long radicle were transplanted individually into pots $(8.5 \mathrm{~cm}$ in height and $10 \mathrm{~cm}$ in diameter) containing a commercial growing medium (Kronos N 50-300 mg/L, $\mathrm{P}_{2} \mathrm{O}_{5} 80-300 \mathrm{mg} / \mathrm{L}, \mathrm{K}_{2} \mathrm{O} 80-300 \mathrm{mg} / \mathrm{L}$, pH 5-6.5, salinity <1.75 g/L). The pots were placed in a growth chamber under a $16 / 8$-h day/night regime, $23{ }^{\circ} \mathrm{C}, 55-65 \%$ relative humidity in a completely randomized block (block in the treatments). All pots were randomized within each treatment biweekly. The salt treatments started four days after transfer to pots. The following treatments were implemented: (1) control, no salt; (2) salt stress, with initial treatment of $50 \mathrm{mM} \mathrm{NaCl}$ and gradual step acclimatization to 50-100 and 50-100-150 mM final NaCl concentrations; and (3) salt shock, with initial treatment of 100 and $150 \mathrm{mM} \mathrm{NaCl}$ concentrations. Thus, the experiment consisted of six sample sets, each comprising control (no salts) and five salt treatments, three of salt stress (50, 50-100 and 50-100-150 mM NaCl), and two of salt shock $(100,150 \mathrm{mM} \mathrm{NaCl})$. Each set had three independent biological replicate pools of four plants. The gradual acclimatization started four days post-transplanting, and the salt concentration was increased in three steps of 10 days from 0 to 50,100 , and $150 \mathrm{mM} \mathrm{NaCl}$ or in two steps of 15 days from 0 to 50 and from 50 to $100 \mathrm{mM}$. Plants were watered every five days when salt treatments started. Once per week, Hoagland solution [38] was added to the salt solution. The growth chamber culture lasted 34 days. Whole shoots, excluding cotyledons and the roots, were transferred in situ into liquid nitrogen in the middle of the light period. When harvested, all plants were in the vegetative stage, and roots did not show nodules. The plants of Alborea at initial salt shock of 100 and $150 \mathrm{mM} \mathrm{NaCl}$ were not harvested as they did not survive. 


\subsection{Growth Characteristics Measurements}

The length of the stems from the base to the tip was measured in each seedling at an interval of three days through the duration of the salt treatments. Stem elongation rate (SER) was estimated as $\mathrm{SER}=(\mathrm{T} 2-\mathrm{T} 1) / \mathrm{t}$, where $\mathrm{T} 1$ and $\mathrm{T} 2$ represent the stem length at the beginning and at the end of a time $t$, respectively. Additionally, the salinity sensitivity index (IS) based on the stem length was estimated according to the formula proposed by Reference [39], IS $=(\mathrm{Hs}-\mathrm{Ht}) / \mathrm{Ht} \times 100$, in which $\mathrm{Hs}$ and $\mathrm{Ht}$ represent the values of stem length of the salt-stressed and control plants, respectively.

\subsection{Determination of $\mathrm{Na}^{+}$and $\mathrm{K}^{+}$Contents}

Leaves and roots from the harvested plants were dried at $65{ }^{\circ} \mathrm{C}$ for $48 \mathrm{~h}$. Dried material was ground to powder and the concentrations of $\mathrm{Na}^{+}$and $\mathrm{K}^{+}$were determined using flame photometry (Corning 410, Sherwood Scientific Ltd., Cambridge, UK). As there was not enough plant material, particularly for the initial treatments of 100 and $150 \mathrm{mM} \mathrm{NaCl}$ concentrations, the three replicates were bulked into one. Additionally, there was no plant material of Alborea for these two treatments. The data of $\mathrm{Na}^{+}$and $\mathrm{K}^{+}$determination were not subject to statistical analysis, and therefore, are considered indicative.

\subsection{RNA Isolation and Complementary DNA Synthesis}

Total RNA was extracted using the Trizol reagent (Sigma-Aldrich, St. Louis, MO, USA) method according to the manufacturer's protocol. Nucleic acid concentration and quality were assessed using NanoDrop ${ }^{\mathrm{TM}}$ ultraviolet (UV) spectrophotometry and by agarose gel electrophoresis. For the complementary DNA (cDNA) synthesis experiment, first-strand cDNA was synthesized from $0.5 \mu \mathrm{g}$ of total RNA using the Superscript II enzyme (Invitrogen, Carlsbad, CA, USA) following the manufacturer's instructions.

\subsection{Real-Time PCR Experiments}

Quantitative PCR was performed with a Step One Plus Real-Time PCR system (Applied Biosystems, Foster City, CA, USA) using SYBR Select Master Mix (Applied Biosystems, Foster City, CA, USA). Primer design was accomplished using the Primer blast NCBI otool (Primer Blast, https:/ /www. ncbi.nlm.nih.gov/tools/primer-blast/), using expressed sequence tags (ESTs) of M. sativa that were deposited in National Center for Biotechnology Information (NCBI), except for the AP2/EREB-like AINTEGUMENTA gene. A phylogenetic analysis of the AP2/EREB-like AINTEGUMENTA protein from M. truncatula and various AP2/EREB members was performed using the MEGA7 software, Pennsylvania State University, State College, PA, USA) [40]. Best primer pairs were selected utilizing an oligo-analyzer tool. The gene-specific primers which were used are listed in Table 1, and the synthesized cDNA was adjusted to a final concentration of $1.5 \mathrm{ng} / \mu \mathrm{L}$ for qPCR experiments. Serial dilutions of cDNA were used to make a standard curve to optimize amplification efficiency for each primer set. All reactions were performed in triplicate. Melt curves of the reaction products were generated and fluorescence data were collected at a temperature above the melting temperature of non-specific products. Relative expression levels of the studied genes (NHX1, RCI2A, P5CS1, SIMKK, $Z F N$-containing $C C C H$ domain, and $A P 2 / E R E B$ ) were calculated according to the $2^{-\triangle \Delta C t}$ method [41] (for calculating $\Delta \Delta \mathrm{Ct}$ value, the control sample of each entry was used). Actin-2 was used as an internal control for normalization. 
Table 1. The real-time PCR primers of Msactin2, MsRCI2A, MsNHX1, MsAP2/EREB, MsSIMKK, MsZFN, and MsP5CS1.

\begin{tabular}{cccc}
\hline Sequence Name & Genbank Number & \multicolumn{1}{c}{ Primer Sequence } & Amplicon Size \\
\hline $\begin{array}{c}\text { Ms-actin2-F } \\
\text { Ms-actin2-R }\end{array}$ & JQ028730.1 & TTCTCACCACACTTCTCGCC & $173 \mathrm{bp}$ \\
Ms-AP2/EREB-F & Not deposited & AATGGGTGGGGAAACGGAAC & 95 bp \\
Ms-AP2/EREB-R & & TTTGGTGGTGGAGTGTGGTT & \\
\hline Ms-NHX1-F & AY513732.1 & GCCATGAAATTCACCGACCG & $118 \mathrm{bp}$ \\
Ms-NHX1-R & & CTGCCACCAAAAACAGGACG & \\
Ms-P5CS-F & X98421.1 & TTTGCGGTCGGAAGGTGTTA & $119 \mathrm{bp}$ \\
Ms-P5CS-R & & CGATTTCCAAGGTGCAAGCC & \\
Ms-ZFN-F & JX131368.1 & CCCAAGCTGCAAGTTTGACC & $154 \mathrm{bp}$ \\
Ms-ZFN-R & & TGAGCCCGACTCAACAAGTC & \\
\hline Ms-SIMKK-F & AJ293274.1 & ACCAGAAGCTCCAACGACTG & $94 \mathrm{bp}$ \\
Ms-SIMKK-R & & CCTCGAAGCAGTCCATCTCC & \\
\hline Ms-RCI2-F & JQ665271.1 & GTTGTCAGGGGCGTCATTCT & $169 \mathrm{bp}$ \\
Ms-RCI2-R & & TCCAAGCAGGACAAAACGGA & \\
\hline
\end{tabular}

\subsection{Statistical Analysis}

The repeated-measures ANOVA with the generalized linear model (GLM) was used for detecting the effect of treatment and species on seedlings height and SER. The within-subject factors were the dates and the treatments were the between-subject factor for the species. Additionally, a three-wayANOVA was performed in order to detect the effect of treatments, species, and organs on gene expression. Tukey's test at the 0.05 probability level was used to detect the differences among means [42]. The IBM SPSS Statistics 23 software (SPSS Inc., Chicago, IL, USA) was used for the statistical analysis. A heat map was generated using Excel 2016, for a visual summary of gene expression.

\section{Results}

\subsection{Growth Parameters and Salinity Sensitivity Index}

Significant differences in plant height, stem elongation rate (SER), and salinity sensitivity indexes were recorded among salt treatments, parent species and Alborea (hereafter entries), and dates of treatment (Table 2). However, significant interaction was detected between salt treatments and entries for all the growth parameters, indicating a differentiated response of the entries to the salt treatments (Table 2). Overall, the growth parameters, i.e., seedling height and SER, were significantly reduced under salt treatments, and especially, under salt shock with 100 and $150 \mathrm{mM} \mathrm{NaCl}$ initial treatment, where the lowest values were recorded (Figure 1). The studied population of Alborea had significantly higher plant height and SER compared to the others under control and $50 \mathrm{mM} \mathrm{NaCl}$ initial treatment (Figure 1). On the other hand, the population of Alborea had the lowest value for all growth parameters at the 100 and $150 \mathrm{mM} \mathrm{NaCl}$ initial treatment, and those of the studied population of $M$. sativa were highest for the gradual acclimatizations (Figure 1). Furthermore, the lowest salinity sensitivity index was recorded for the population of $M$. sativa at the gradual acclimatization followed by that of $M$. arborea at $50 \mathrm{mM}$ initial treatment and at 50-100 mM gradual acclimatization (absolute numbers; Figure 2). The highest salinity sensitivity index (absolute number) was detected for the population of Alborea under salt sock at 100 and $150 \mathrm{mM} \mathrm{NaCl}$ initial treatments. 
Table 2. Statistical significance of F ratios from the analysis of variance for stem height of seedlings, stem elongation rate (SER), and sensitivity index.

\begin{tabular}{cccc}
\hline Source of Variation & Height & SER & Salinity Sensitivity Index \\
\hline Salt (A) & $p<0.05$ & $p<0.05$ & $p<0.05$ \\
Species (B) & $p<0.05$ & $p<0.05$ & $p<0.05$ \\
Dates (C) & $p<0.05$ & $p<0.05$ & $p<0.05$ \\
$\mathrm{~A} \times \mathrm{B}$ (Interaction) & $p<0.05$ & $p<0.05$ & $p<0.05$ \\
$\mathrm{~A} \times \mathrm{C}$ (Interaction) & $p<0.05$ & $\mathrm{~ns}$ & $\mathrm{~ns}$ \\
$\mathrm{~B} \times \mathrm{C}$ (Interaction) & $\mathrm{ns} *$ & $p<0.05$ & $\mathrm{~ns}$ \\
$\mathrm{~A} \times \mathrm{B} \times \mathrm{C}$ (Interaction) & $\mathrm{ns}$ & $\mathrm{ns}$ & $\mathrm{ns}$ \\
\hline
\end{tabular}

* ns: not significant at 0.05 level.
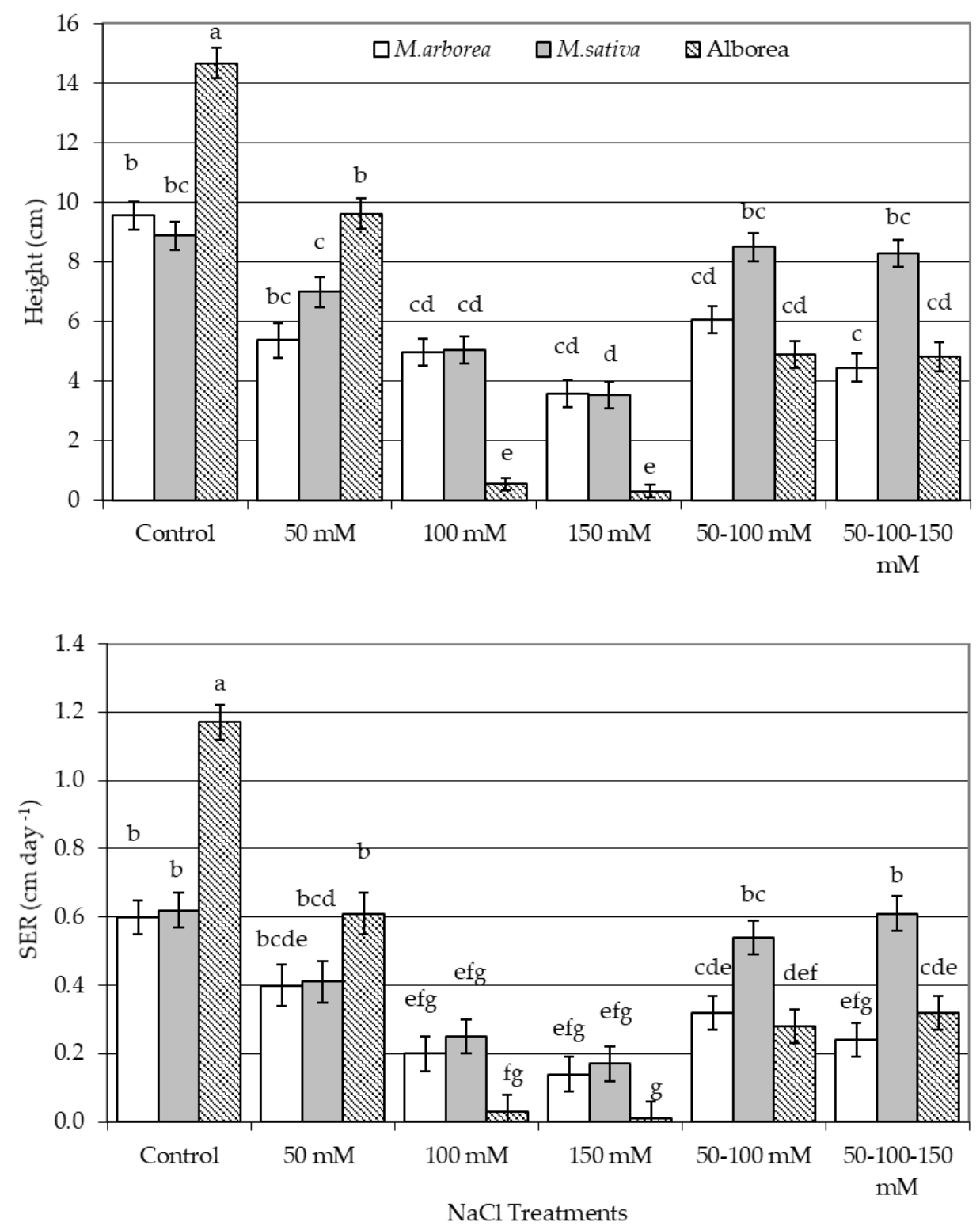

Figure 1. The stem height, and the stem elongation rate (SER) of M. arborea (M. ar), M. sativa (M. sa), and Alborea (Al) under control, 50 mM, 100 mM, 150 mM, 50-100 mM, and 50-100-150 mM NaCl. The vertical bars indicate the mean \pm standard error (SE) of five independent samples. The different letters refer to the significant differences at $p<0.05$ (Tukey's test). 


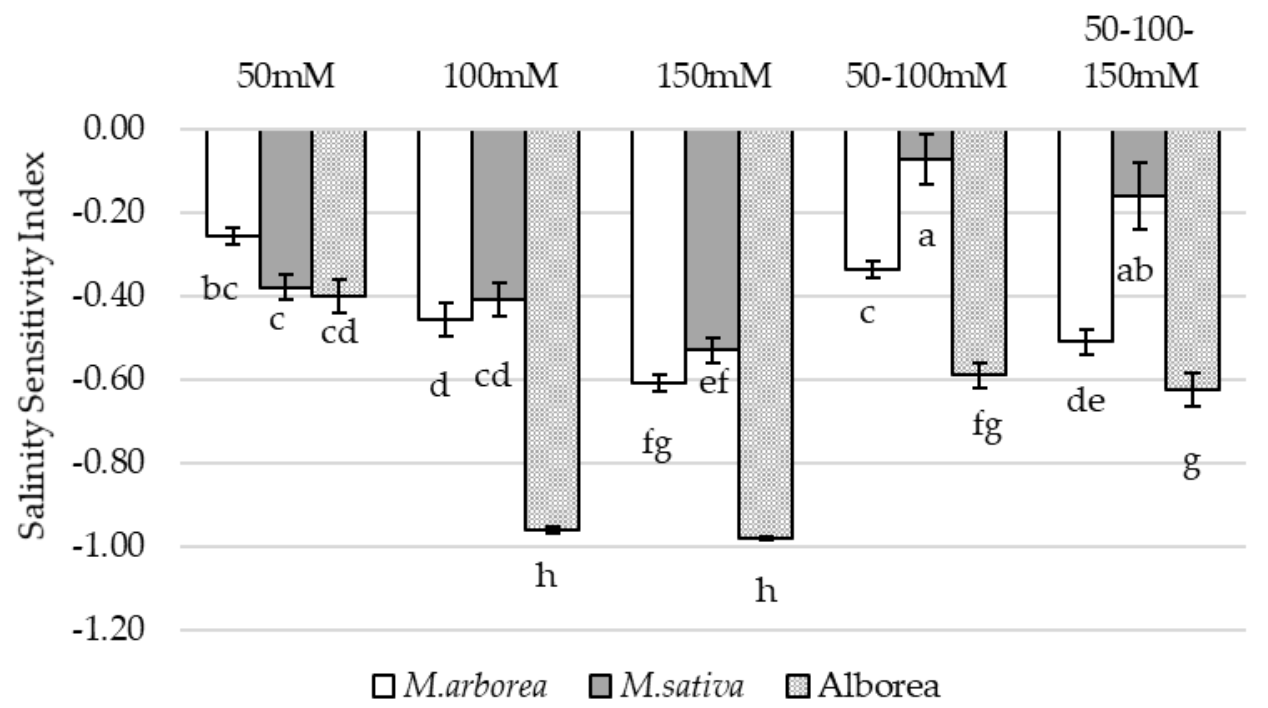

Figure 2. The salinity sensitivity index of M. arborea, M. sativa, and Alborea under control, $50 \mathrm{mM}$, $100 \mathrm{mM}, 150 \mathrm{mM}, 50-100 \mathrm{mM}$, and 50-100-150 mM NaCl. The vertical bars indicate the mean $\pm \mathrm{SE}$ of five independent samples. The different letters refer to the significant differences at $p<0.05$ (Tukey's test).

Significant interaction was detected between salt treatments and dates for seedling heights and between entries and dates for SER (Table 2). Seedling heights gradually increased from the first to the last date of measurements for all the treatments except for those at 100 and $150 \mathrm{mM} \mathrm{NaCl}$ initial treatments, where they remained almost unchanged (Figure 3). On the other hand, the SER of the Alborea population remained steady during the experimental period independent of salt treatment, while, for the populations of $M$. arborea and M. sativa, it tended to decrease from the first to the final date of treatments (Figure 3).

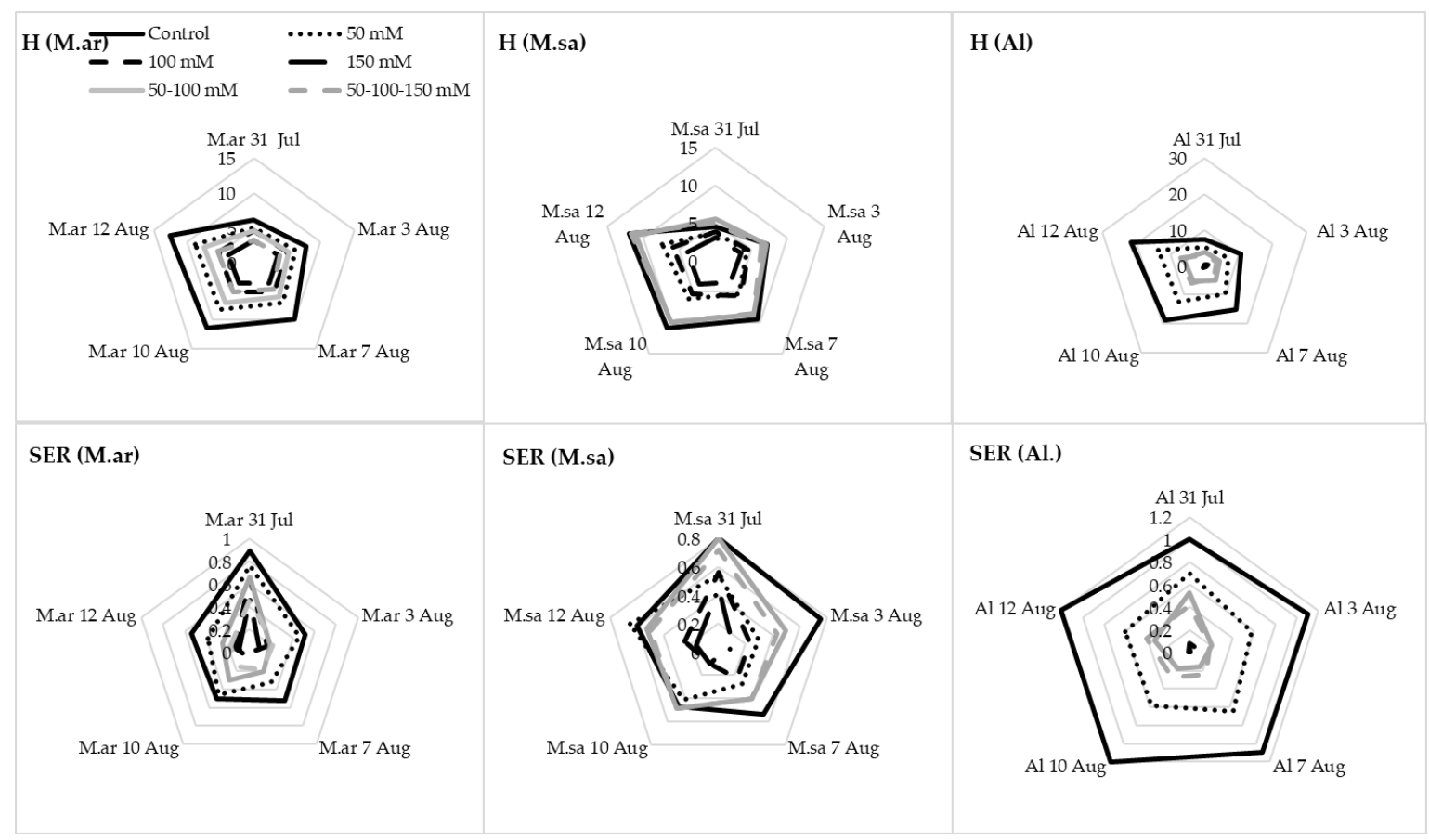

Figure 3. Stem height $(\mathrm{H})$ and stem elongation rate (SER) of $M$. arborea (M. ar), M. sativa (M. sa), and Alborea (Al) as affected by control, $50 \mathrm{mM}, 100 \mathrm{mM}, 150 \mathrm{mM}, 50-100 \mathrm{mM}$, and 50-100-150 mM NaCl during the experimental period. 
Regarding the $\mathrm{Na}^{+}$and $\mathrm{K}^{+}$concentrations in leaves, the results are only indicative, as there was not enough tissue from all the treatments, especially for Alborea. According to the results, the $\mathrm{Na}^{+}$ concentration was much lower in leaves of the M. sativa population under salt shock, compared to those of M. arborea and of Alborea (Table 3). The $\mathrm{K}^{+}$concentration tended to decrease with the increase in $\mathrm{NaCl}$ concentration for the populations of M. arborea and Alborea, while it remained at the same level for that of M. sativa.

Table 3. Indicative data of sodium and potassium content $\left(\mathrm{mg} \cdot \mathrm{g}^{-1}\right.$ dry weight $\left.(\mathrm{dw})\right)$ of $M$. arborea, M. sativa, and Alborea.

\begin{tabular}{cccc}
\hline & & $\mathbf{K}^{+}$ & $\mathbf{N a}^{+}$ \\
\hline \multirow{2}{*}{ M. arborea } & Control & 38.5 & 1.1 \\
& $\left.50 \mathrm{mM} \cdot \mathbf{g}^{-\mathbf{1}} \mathbf{d w}\right)$ & $\left.\mathbf{( m g} \cdot \mathbf{g}^{-\mathbf{1}} \mathbf{d w}\right)$ \\
& $50-100 \mathrm{mM}$ & 24.4 & 10.6 \\
& $50-100-150 \mathrm{mM}$ & 31.8 & 20.4 \\
M. sativa & Control & 22.8 & 21.7 \\
& $50-100 \mathrm{mM}$ & 21.5 & 3.5 \\
& $50-100-150 \mathrm{mM}$ & 25.1 & 6.9 \\
Alborea & Control & 51.2 & 5.1 \\
& $50 \mathrm{mM}$ & 38.1 & 2.3 \\
& $50-100 \mathrm{mM}$ & 13.4 & 19.6 \\
& & & 23.4 \\
\hline
\end{tabular}

\subsection{Gene Expression Levels}

The main effects and the interactions between each entry/type of plant organ and different treatments on the expression levels of the studied genes are presented in Table 4. Interactions were statistically significant in most cases. On average, NHX1 and AP2/EREB transcripts were the most highly abundant in all entries (Figure 4). The transcript levels of both genes were highly responsive during salt gradual acclimatization and salt shock, followed by RCI2A and P5CS1.

In general, the expression levels of all transcripts were higher in the studied population of M. arborea followed by that of M. sativa. On the other hand, in the studied population of Alborea, the lowest induction of all genes was detected under salt treatments (Figure 5). The induction of all genes in most cases was proportional to the $\mathrm{NaCl}$ concentration, and the highest induction levels were detected after $150 \mathrm{mM} \mathrm{NaCl}$ or $50-100-150 \mathrm{mM} \mathrm{NaCl}$ treatment (Figure 5). The lowest increase in transcript levels for all genes was detected in plants treated with $50 \mathrm{mM} \mathrm{NaCl}$ or with $50-100 \mathrm{mM}$ $\mathrm{NaCl}$ gradual acclimatization (Figure 5).

Table 4. Statistical significance of F ratios from the analysis of variance for gene expression.

\begin{tabular}{ccccccc}
\hline Source of Variation & RCI2A & NHX1 & AP2/EREB & SIMKK & ZFN & P5CS_1 \\
\hline Salt (A) & $p<0.05$ & $p<0.05$ & $p<0.05$ & $p \leq 0.05$ & $p \leq 0.05$ & $p \leq 0.05$ \\
Species (B) & $p<0.05$ & $p<0.05$ & $p<0.05$ & $p \leq 0.05$ & $p \leq 0.05$ & $p \leq 0.05$ \\
Organs (C) & $p<0.05$ & $p<0.05$ & $p<0.05$ & $p \leq 0.05$ & $p \leq 0.05$ & $p \leq 0.05$ \\
$\mathrm{~A} \times \mathrm{B}$ (Interaction) & $p<0.05$ & $p<0.05$ & $p<0.05$ & $p \leq 0.05$ & $\mathrm{~ns}$ & $p \leq 0.05$ \\
$\mathrm{~A} \times \mathrm{C}$ (Interaction) & $p<0.05$ & $\mathrm{~ns}^{*}$ & $p<0.05$ & $p<0.05$ & $p \leq 0.05$ & $\mathrm{~ns}$ \\
$\mathrm{~B} \times \mathrm{C}$ (Interaction) & $p<0.05$ & $p<0.05$ & $p<0.05$ & $\mathrm{~ns}$ & $\mathrm{~ns}$ & $p \leq 0.05$ \\
$\mathrm{~A} \times \mathrm{B} \times \mathrm{C}$ & $p<0.05$ & $p<0.05$ & $p<0.05$ & $p<0.05$ & $p \leq 0.05$ & $p \leq 0.05$ \\
(Interaction) & & & & & & \\
\hline
\end{tabular}

*ns: not significant at 0.05 level. 


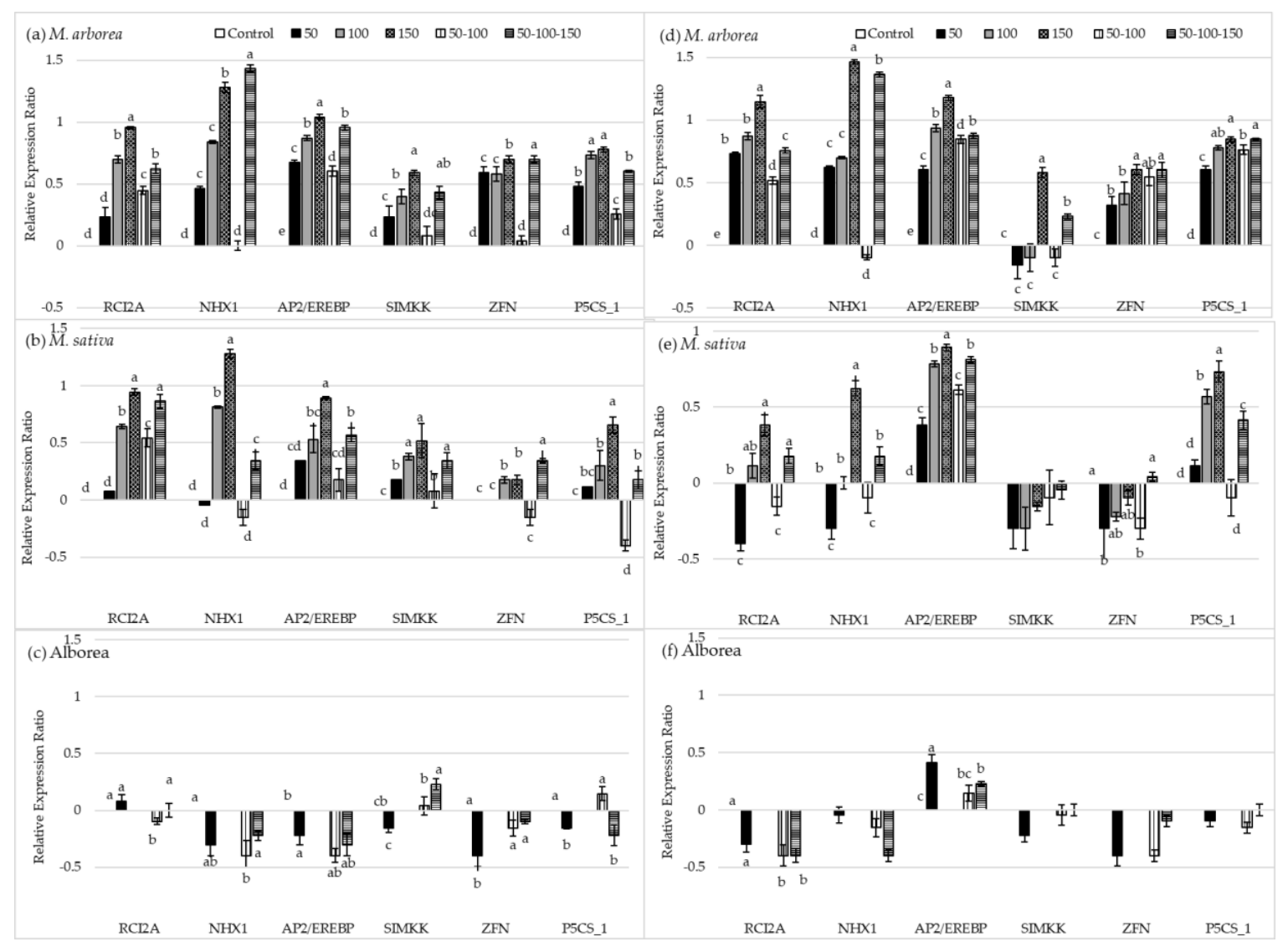

Figure 4. RCI2A, NHX1, AP2/EREB, SIMKK, ZFN, and P5CS relative expression levels for M. arborea, M. sativa, and Alborea under control, $50 \mathrm{mM}, 100 \mathrm{mM}, 150 \mathrm{mM}, 50-100 \mathrm{mM}$, and 50-100-150 mM NaCl for leaves $(\mathbf{a}-\mathbf{c})$ and roots $(\mathbf{d}-\mathbf{f})$. The vertical bars indicate the mean $\pm \mathrm{SE}$ of three independent samples. The different letters refer to the significant differences at $p<0.05$ (Tukey's test).

All gene transcripts showed the strongest induction in the population of $M$. arborea, and to the same extent in both leaves and roots, apart from SIMKK (Figure 4a,d). Moreover, in most cases, gene induction was proportional to the final concentration of $\mathrm{NaCl}$ regardless of the type of treatment (stress or shock). On the other hand, in leaves of the M. sativa population, AP2/EREB, NHX1, and P5CS1 had higher induction levels in salt shock treatments compared to salt stress ones (Figure $4 \mathrm{~b}, \mathrm{e}$ ). Inversely, the transcript accumulation of $\mathrm{RCI} 2 \mathrm{~A}$ was dependent on the final concentration of $\mathrm{NaCl}$ regardless of stress or shock treatment. Additionally, the transcript abundance of all genes, except for AP2/EREB and P5CS1, was higher in leaves of the M. sativa population than in roots (Figure 4b,e). Finally, regarding the population of Alborea, a low induction of only SIMKK transcripts was detected in leaves and of $A P 2 / E R E B$ in roots (Figure 4c,f, respectively). A heat map was constructed in order to visualize possible differences in the relative change of each transcript level among the treatments and the entries (Figure 5). According to the heat map, the population of Alborea exhibited the lowest induction of all genes. Moreover, the most abundant gene transcripts were found for NHX1 and $A P 2 / E R E B$. The difference in gene induction is evident between leaves and roots in the populations of $M$. arborea and M. sativa, as well as the fact that gene induction in the roots of the population of M. sativa is much lower compared to leaves. 


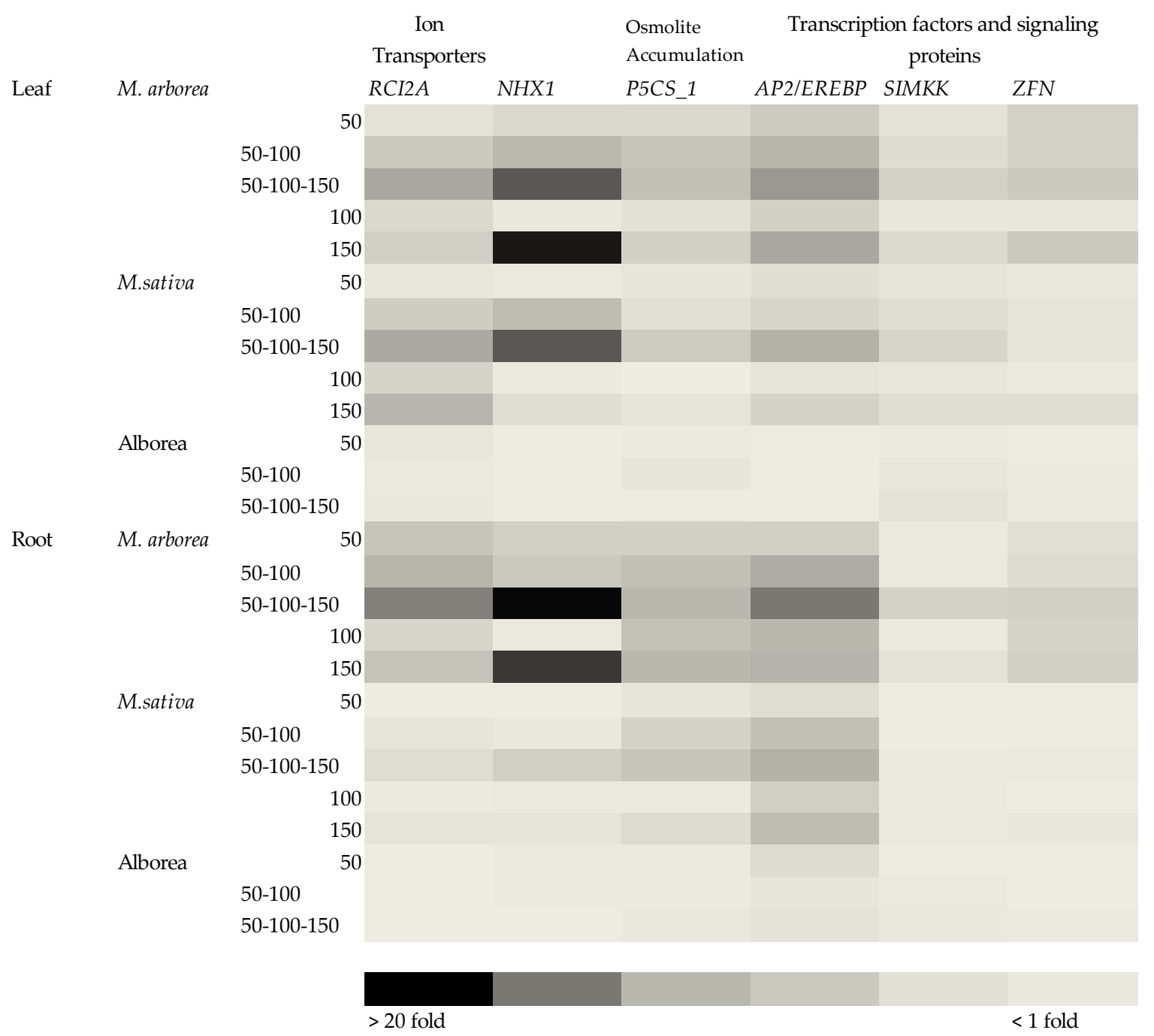

Figure 5. General expression levels of RCI2A, NHX1, AP2/EREB, SIMKK, ZFN, and P5CS under salt shock and salt stress for M. arborea, $M$. sativa, and Alborea. Expression levels are black and white-coded to depict the fold change as follows: black (high expression level $>20$-fold) to white (low $<1$ fold).

\section{Discussion}

\subsection{Growth of Seedlings under Salinity}

In the present study, salinity tolerance was tested in populations of two Medicago species, M. sativa and M. arborea, and in their hybrid Alborea. Two salinity regimes were applied: salt stress and salt shock. Plants differed greatly in their tolerance to salinity, as indicated by seedling growth parameters and the sensitivity index. However, the effect was much more severe for salt shock at $100 \mathrm{mM}$ and $150 \mathrm{mM} \mathrm{NaCl}$ compared to the gradual acclimatization, reducing the seedling growth parameters and increasing the sensitivity index, on average, by about $70 \%$ to $80 \%$, compared to the control. The suppression of plant growth under salinity is generally attributed to the osmotic effects of the salt in the soil in combination with ionic effects of the salt concentration in plant tissues. The plants suffer from a much more intense osmotic stress or plasmolysis under sudden $\mathrm{NaCl}$ application than under a gradual one [9]. In this regard, the concentration of shoot $\mathrm{Na}^{+}$was higher and the growth reduction was greater in wheat plants under salt shock compared to those under gradual application [43]. Similarly, Reference [44] reported that $150-200 \mathrm{mM} \mathrm{NaCl}$ salt shock had a lethal effect on rice plants, while a similar effect was not documented for the gradual acclimatization of $\mathrm{NaCl}$ to the same level [10]. 
In our study, seedling growth parameters decreased as the salt level increased for the studied populations of $M$. sativa, $M$. arborea, and their hybrid. The reduced growth of seedlings or more mature plants of different $M$. sativa cultivars under either salt shock [20,45] or salt stress $[16,46,47]$ were broadly reported. A similar reduction in plant growth under salt stress gradually applied was reported for M. arborea $[24,25,48,49]$.

Differences in the response of the populations of M. sativa, M. arborea, and their hybrid to salt shock and salt stress were also observed. The hybrid performed better than its parents under control and low salinity level $(50 \mathrm{mM})$, while the population of $M$. sativa performed better under gradual salt acclimatization. On the other hand, the salt shock of 100 and $150 \mathrm{mM} \mathrm{NaCl}$ had a detrimental effect on the hybrid, causing the death of plants seven days after the salt application, whereas its parents continued their growth until the end of the experiment. Additionally, the population of M. sativa presented a consistently lower salinity sensitivity index under all salt treatments compared to that of $M$. arborea and the hybrid. According to the results, it seems that the studied population of $M$. sativa is more tolerant to salinity compared to that of $M$. arborea in terms of seedling growth. Other studies conducted with $M$. sativa varieties also featured a correlation between tolerance to salt stress and low salinity sensitivity index, which was also evaluated for stem length [20]. However, the different growth forms of the species could be a factor, in that M. sativa is a perennial herbaceous species, whereas $M$. arborea is woody. The response of plants to stresses at the seedling stage is highly related to their growth form [50] and, generally, perennial herbaceous species are characterized by higher relative growth rates in the seedling stage.

\subsection{Gene Expression under Salt Treatments}

To further explore the response mechanisms of the parent species and their hybrid to salinity, the relative expression ratios of several salt-induced genes were evaluated. The ion transporters NHX1 and $R C I 2 A$ control the uptake of cations and/or the efflux of anions, and they function as membrane stabilizers. In particular, NHX1 is a vacuole transporter [51] and its role in the cell is the transport of $\mathrm{K}^{+}$or $\mathrm{Na}^{+}$into the vacuole exchanging $\mathrm{H}^{+}$efflux to the cytosol, maintaining a low $\mathrm{Na}^{+} / \mathrm{K}^{+}$cytosolic ratio. Proteins encoded by $R C I 2 A$ act within plasma membranes and they possibly modulate ion transporters or stabilize membrane proteins that affect ion transport [52]. Both gene transcripts were highly accumulated in roots and leaves of the $M$. arborea population and their relative expression was influenced only by the final $\mathrm{NaCl}$ concentration. On the other hand, NHX1 and RCI2A upregulation was recorded mainly in leaves of the $M$. sativa population. Additionally, there was a profound upregulation of NHX1 relative expression under salt shock compared to gradual acclimatization of $\mathrm{NaCl}$ mainly in the leaves of the $M$. sativa population. Recent findings by Leidi et al. [31] indicate that proteins encoded by RCI2A may be involved in the salt tolerance of M. sativa and M. truncatula. Moreover, research conducted by Sandhu et al. [23] highlighted the importance of NHX1 to the salt tolerance of M. sativa.

Organic solutes are key players in increasing tolerance of plant tissues to excessive salt concentrations. P5CS1 controls the de novo synthesis of proline and its accumulation during salt stress [53]. Several studies associate proline abundance with plant adaptability to drought and salt stress $[54,55]$. Results of the present study indicate that relative transcript levels were highly abundant in leaves and roots of the M. arborea population in both salt shock and stress treatments. However, the P5CS1 in the studied population of M. sativa (both roots and leaves) under salt shock was upregulated almost 5.5-fold, while, under salt stress, the induction was lower (0-2-fold).

The $A P 2 / E R F$ transcription factors comprise a large group of genes, which is divided into four subfamilies, namely $A P 2, E R F, D R E B$, and $R A V$ [56,57]. Moreover, the AP2 subfamily consists of two subgroups, AP2 and AINTEGUMENTA [58]. Phylogenetic tree analysis revealed that the M. sativa AINTEGUMENTA-like transcription factor was identical to the M. truncatula homologous protein and very similar to the Cicer arietium protein, as well as to Arachis ipaensis, Vigna anqularis, and Phaseolus vulgaris homologous proteins (Supplementary Materials). Interestingly, 
not many studies demonstrated the contribution of AINTEGUMENTA subfamily members to abiotic tolerance. Meng et al. [59] reported that AINTEGUMENTA genes regulate salt tolerance in Arabidopsis. The findings of the present study highlight the importance of an AP2/EREB transcription factor belonging to the AINTEGUMENTA subgroup during the response of the studied populations of $M$. sativa and M. arborea to salt treatments. The trend of AINTEGUMENTA upregulation in most cases was the same as described for the aforementioned genes. It is noteworthy that AINTEGUMENTA gene was the only gene that was highly expressed in roots of $M$. sativa's population under both salt stress and salt shock.

MAP kinases are represented by multigene families in plants that perceive and transmit various signals including specific stimuli from abiotic stresses [60]. Specifically, the studied SIMKK gene was previously found to upregulate the downstream SIMKK gene and induce salt tolerance in alfalfa [61]. Moreover, transcription factors such as zinc finger proteins (ZFPs) regulate gene expression under many abiotic stresses including salt [62]. The expression level of ZFN was highly induced after salt treatment in alfalfa tolerant varieties [36,63]. In the present study, there was a fivefold upregulation of ZFN under salt shock $(150 \mathrm{mM} \mathrm{NaCl})$ and salt stress of 50-100-150 gradual acclimatization for the studied population of M. arborea. However, in that of M. sativa, no profound differences were observed between control and salt-treated plants. In general, a similar expression pattern was detected for the SIMKK gene.

Findings in the present study indicate that differences occur between expression ratios of salt shock (initial salt treatments of 100 and $150 \mathrm{mM}$ ) and salt stress (initial salt treatments $50 \mathrm{mM}$ and gradual 50-100 and 50-100-150 mM) depending on the type of gene, the species, and the plant part. Among the studied genes, it seems that the ion transporters NHX1 and RCI2A, the transcription factor of the AINTEGUMENTA subgroup, and the organic solute P5CS1 play critical roles in the response of studied populations of $M$. sativa and M. arborea to both salt shock and salt stress. In experiments conducted in Lotus japonicus [14] using gradual salt stress treatment (up to $150 \mathrm{mM} \mathrm{NaCl}$ ), it was reported that the most responsive genes were clearly related to transcription and signaling pathways and were likely to be involved in ionic changes and not involved in osmoregulation [10]. Moreover, some studies demonstrated clear differences between the genes that were upregulated between salt shock and stress in parallel experiments $[64,65]$. In our case, the same genes are key players to both salt shock and stress. This is probably attributed to the fact that, in salt-shock-treated plants, the ionic phase occurs early [10] and, as a result, expression changes of genes related to ionic stress responses can be detected especially after long exposure to salt shock (about four weeks in our case).

The population of $M$. arborea constitutively expresses all studied genes even under control conditions. Moreover, it upregulates all studied genes regardless of the salt regime (salt stress or salt shock). This strategy of $M$. arborea appears to have a negative impact on its growth rate probably due to the large energy cost. For example, as mentioned by many authors, proline synthesis is a metabolically expensive strategy $[66,67]$. On the other hand, a clear difference in gene expression levels under the two salt regimes was detected in the population of $M$. sativa. It seems that some responses are not necessary at low salt concentrations and are activated only when a threshold is reached [14]. The key genes according to the present study were moderately or hardly upregulated under salt stress, and highly under salt shock, indicating that $M$. sativa "orchestrates" a fine-tuning of gene induction up to the point it combines both salinity tolerance and the lowest growth reduction.

According to Sanches et al. [14], sensitive genotypes can compensate under low salt stresses, which is also the case with Alborea. The hybrid performed better than its parents under low concentrations of $\mathrm{NaCl}$. This could be due to tolerance to low concentrations. In any case, it cannot efficiently respond under moderate-to-high salt concentrations.

We can conclude that the hybrid of $M$. sativa and M. arborea was much more productive compared to its parents under normal conditions and low salt treatments, but extremely sensitive to salt stress. On the other hand, the studied populations of $M$. sativa and M. arborea were relatively tolerant to all 
salt treatments. Furthermore, the population of M. sativa performed better than that of M. arborea under both salt stress and salt shock at the seedling stage, probably by activating a more cost-efficient strategy.

The two parental species of Alborea appear to regulate different components of the salt tolerance mechanism. There was no selection for salt tolerance in the development of the Alborea population used in our experiments; thus, Alborea plants could be genetically deficient for both mechanisms. Fortunately, the Alborea population was developed from several initial hybrids. Hence, all the genes for both mechanisms for salt tolerance should be present in the population per se, and potentially could be pyramided in individual plants by cycles of selection for salt tolerance.

Further investigation of the mechanisms of M. sativa and M. arborea through transcriptomic and metabolomic analysis, as well as under field conditions, could contribute to a better understanding of salt stress tolerance. Specific attention should be given to further analyze the function of AINTEGUMENTA under both salt shock and stress. This could be valuable when breeding salt tolerance into the highly productive hybrid.

Supplementary Materials: The following are available online at http:/ /www.mdpi.com/2073-4395/8/10/231/s1, Figure S1: Phylogeny analysis of $M$. sativa AINTEGUMENTA protein with other AP2/EREB transcription factors. The GenBank accession numbers are as follows: AP2 like Phaseolus vulgaris (ESW30355.1), AIL6 Vigna angularis var. angularis (BAT99446.1), AIL6 Arachis ipaensis (XP_016201070.1), AIL like Medicago truncatula (XM_003612982.1), AIL6 Cicer arietinum (XP_004509770), AIL6 Lupinus angustifolius (XP_019421574.1), AIL6 Cucurbita moschata (XP_022942874), AIL6 Gossypium raimondii (KJB18166.1), AP2 like Citrus clementina (ESR39494.1), AIL6 Nicotiana attenuate (O1T03126.1) and AP2 like Coffea canephora (CDP01573.1).

Author Contributions: Conceptualization, E.T. and E.M.A. Methodology, E.T. and E.M.A. Formal analysis, E.M.A. Investigation, E.S., M.G., G.A., and M.P. Resources, E.B. Data curation, E.S. Writing-original draft preparation, E.T. and E.M.A. Writing-review and editing, E.B. Visualization, E.M.A. Supervision, E.T. and E.M.A. Project administration, E.T. and E.M.A. Funding acquisition, G.N.S.

Funding: This research received no external funding.

Acknowledgments: We would like to thank Antonia Tzampazy and Joseph Pentheroudakis (native English speakers) for carefully editing our manuscript.

Conflicts of Interest: The authors declare no conflict of interest.

\section{References}

1. Pitman, M.G.; Läuchli, A. Global impact of salinity and agricultural ecosystems. In Salinity: EnvironmentPlants-Molecules; Läuchli, A., Luttge, U., Eds.; Springer: Dordrecht, The Netherlands, 2002; pp. 3-20.

2. Rengasamy, P. Soil chemistry factors confounding crop salinity tolerance-A review. Agronomy 2016, 6, 53. [CrossRef]

3. Young, J.; Udeigwe, T.K.; Weindorf, D.C.; Kandakji, T.; Gautam, P.; Mahmoud, M.A. Evaluating management-induced soil salinization in golf courses in semi-arid landscapes. Solid Earth 2015, 6, $393-402$. [CrossRef]

4. Pariente, S. Soluble salts dynamics in the soil under different climatic conditions. Catena 2001, 43, 307-321. [CrossRef]

5. Ispail, A.; Takeda, S.; Nick, P. Life and death under salt stress: Same players, different timing? J. Exp. Bot. 2014, 65, 2963-2979.

6. Munns, R.; James, R.A. Screening methods for salinity tolerance: A case study with tetraploid wheat. Plant. Soil 2003, 253, 201-218. [CrossRef]

7. Shavrukov, Y.; Langridge, P.; Tester, M. Salinity tolerance and sodium exclusion in genus Triticum. Breed. Sci. 2009, 59, 671-678. [CrossRef]

8. Apse, M.P.; Aharon, G.S.; Snedden, W.A.; Blumwald, E. Salt tolerance conferred by overexpression of a vacuolar $\mathrm{Na}^{+} / \mathrm{H}^{+}$antiport in Arabidopsis. Science 1999, 285, 1256-1258. [CrossRef] [PubMed]

9. Munns, R. Comparative physiology of salt and water stress. Plant Cell Environ. 2002, 25, 239-250. [CrossRef] [PubMed]

10. Shavrukov, Y. Salt stress or salt shock: Which genes are we studying? J. Exp. Bot. 2013, 64, 119-127. [CrossRef] [PubMed] 
11. Munns, R. Genes and salt tolerance: Bringing them together. New Phytol. 2005, 167, 645-663. [CrossRef] [PubMed]

12. Chakraborty, K.; Sairam, R.K.; Bhattacharya, R.C. Differential expression of salt overly sensitive pathway genes determines salinity stress tolerance in Brassica genotypes. Plant Physiol. Biochem. 2012, 51, 90-101. [CrossRef] [PubMed]

13. Roshandel, P.; Flowers, T. The ionic effects of $\mathrm{NaCl}$ on physiology and gene expression in rice genotypes differing in salt tolerance. Plant Soil 2009, 315, 135-147. [CrossRef]

14. Sanchez, D.H.; Lippold, F.; Redestig, H.; Hannah, M.A.; Erban, A.; Krämer, U.; Kopka, J.; Udvardi, M.K. Integrative functional genomics of salt acclimatization in the model legume Lotus japonicus. Plant J. 2008, 53, 973-987. [CrossRef] [PubMed]

15. Munns, R.; Tester, M. Mechanisms of salinity tolerance. Annu. Rev. Plant Biol. 2008, 59, 651-681. [CrossRef] [PubMed]

16. Li, R.; Shi, F.; Fukuda, K.; Yang, Y. Effects of salt and alkali stresses on germination, growth, photosynthesis and ion accumulation in alfalfa (Medicago sativa L.). Soil Sci. Plant. Nutr. 2010, 56, 725-733. [CrossRef]

17. Yang, Q.C.; Wu, M.S.; Wang, P.Q.; Kang, J.M.; Zhou, X.L. Cloning and expression analysis of a vacuolar $\mathrm{Na}^{+} / \mathrm{H}^{+}$antiporter gene from alfalfa. DNA Seq. 2005, 16, 352-357. [CrossRef] [PubMed]

18. Ferreira, J.F.S.; Cornacchione, M.V.; Liu, X.; Suarez, D.L. Nutrient composition, forage parameters, and antioxidant capacity of alfalfa (Medicago sativa, L.) in response to saline irrigation water. Agriculture 2015, 5, 577-597. [CrossRef]

19. Graham, P.H.; Vance, C.P. Legumes: Importance and constraints to greater use. Plant Physiol. 2003, 131, 872-877. [CrossRef] [PubMed]

20. Campanelli, A.; Ruta, C.; Morone-Fortunato, I.; De Mastro, G. Alfalfa (Medicago sativa L.) clones tolerant to salt stress: In vitro selection. Cent. Eur. J. Biol. 2013, 8, 765-776. [CrossRef]

21. Postnikova, O.A.; Shao, J.; Nemchinov, L.G. Analysis of the alfalfa root transcriptome in response to salinity stress. Plant Cell Physiol. 2013, 54, 1041-1055. [CrossRef] [PubMed]

22. Quan, W.L.; Liu, X.; Wang, H.Q.; Chan, Z.L. Physiological and transcriptional responses of contrasting alfalfa (Medicago sativa L.) varieties to salt stress. Plant Cell Tissue Organ Cult. 2016, 126, 105-115. [CrossRef]

23. Sandhu, D.; Cornacchione, M.V.; Ferreira, J.F.S.; Suarez, D.L. Variable salinity responses of 12 alfalfa genotypes and comparative expression analyses of salt-response genes. Sci. Rep. 2017, 7, 42958. [CrossRef] [PubMed]

24. Boughalleb, F.; Denden, M.; Ben Tiba, B. Photosystem II photochemistry and physiological parameters of three fodder shrubs, Nitraria retusa, Atriplex halimus and Medicago arborea under salt stress. Acta Physiol. Plant. 2009, 31, 463-476. [CrossRef]

25. Boughalleb, F.; Denden, M.; Tiba, B.B. Anatomical changes induced by increasing $\mathrm{NaCl}$ salinity in three fodder shrubs, Nitraria retusa, Atriplex halimus and Medicago arborea. Acta Physiol. Plant. 2009, 31, 947-960. [CrossRef]

26. Lefi, E.; Conesa, M.À.; Cifre, J.; Gulías, J.; Medrano, H. Dry matter allocation in Medicago arborea and Medicago citrina in response to drought and defoliation. Crop Pasture Sci. 2012, 63, 179-189. [CrossRef]

27. Bingham, E.T.; Armour, D.; Irwin, J.A.G. The hybridization barrier between herbaceous Medicago sativa and woody M. arborea is weakened by selection of seed parents. Plants 2013, 2, 343-353. [CrossRef] [PubMed]

28. Irwin, J.A.G.; Sewell, J.C.; Woodfield, D.R.; Bingham, E.T. Restructuring lucerne (Medicago sativa) through introgression of the Medicago arborea genome. Agric. Sci. 2016, 28, 40-46.

29. Clifton-Brown, J.C.; Lewandowski, I. Water use efficiency and biomass partitioning of three different Miscanthus genotypes with limited and unlimited water supply. Ann. Bot. 2000, 86, 191-200. [CrossRef]

30. Lei, Y.; Xu, Y.; Hettenhausen, C.; Lu, C.; Shen, G.; Zhang, C.H.; Li, J.G.; Song, J.; Lin, H.; Wu, J. Comparative analysis of alfalfa (Medicago sativa L.) leaf transcriptomes reveals genotype-specific salt tolerance mechanisms. BMC Plant Biol. 2018, 18, 35. [CrossRef] [PubMed]

31. Leidi, E.O.; Barragán, V.; Rubio, L.; El-Hamdaoui, A.; Ruiz, M.T.; Cubero, B.; Fernández, J.A.; Bressan, R.A.; Hasegawa, P.M.; Quintero, F.J.; et al. The AtNHX1 exchanger mediates potassium compartmentation in vacuoles of transgenic tomato. Plant J. 2010, 61, 495-506. [CrossRef] [PubMed]

32. Long, R.C.; Zhang, F.; Li, Z.Y.; Li, M.N.; Cong, L.L.; Kang, J.M.; Zhang, T.J.; Zhao, Z.X.; Sun, Y.; Yang, Q.C. Isolation and functional characterization of salt-stress induced RCI2-like genes from Medicago sativa and Medicago truncatula. J. Plant Res. 2015, 128, 697-707. [CrossRef] [PubMed] 
33. Mitsuya, S.; Taniguchi, M.; Miyake, H.; Takabe, T. Overexpression of RCI2A decreases $\mathrm{Na}^{+}$uptake and mitigates salinity-induced damages in Arabidopsis thaliana plants. Physiol. Plant. 2006, 128, 95-102. [CrossRef]

34. Ashraf, M.; Foolad, M.R. Roles of glycine betaine and proline in improving plant abiotic stress resistance. Environ. Exp. Bot. 2007, 59, 206-216. [CrossRef]

35. Kaur, G.; Asthir, B. Proline: A key player in plant abiotic stress tolerance. Biol. Plant. 2015, 59, 609-619. [CrossRef]

36. Wang, X.H.; Gao, B.W.; Liu, X.; Dong, X.J.; Zhang, Z.X.; Fan, H.Y.; Zhang, L.; Wang, J.; Shi, S.P.; Tu, P.F. Salinity stress induces the production of 2-(2-phenylethyl)chromones and regulates novel classes of responsive genes involved in signal transduction in Aquilaria sinensis calli. BMC Plant Biol. 2016, 16, 119. [CrossRef] [PubMed]

37. Yang, Y.; Guo, Y. Elucidating the molecular mechanisms mediating plant salt-stress responses. New Phytol. 2018, 217, 523-539. [CrossRef] [PubMed]

38. Suh, A. Evaluation of Bioactivity of Phytotoxins from Pathogenic Fungi of Orobanche sp. Ph.D. Thesis, Agricultural University of Athens, Athina, Greece, 2011.

39. Hamrouni, L.; Ben Abdallah, F.; Abdelly, C.; Ghorbel, A. La culture in vitro: Un moyen rapide et efficace pour sélectionner des génotypes de vigne tolérant la salinité. C. R. Biol. 2008, 331, 152-163. [CrossRef] [PubMed]

40. Kumar, S.; Stecher, G.; Tamura, K. MEGA7: Molecular Evolutionary Genetics Analysis Version 7.0 for Bigger Datasets. Mol. Biol. Evol. 2016, 33, 1870-1874. [CrossRef] [PubMed]

41. Livak, K.J.; Schmittgen, T.D. Analysis of relative gene expression data using realtime quantitative PCR and the $2^{-\Delta \Delta C t}$ Method. Methods 2001, 25, 402-408. [CrossRef] [PubMed]

42. Beyer, H.T.; John, W. Exploratory Data Analysis. Addison-Wesley Publishing Company Reading, Mass.-Menlo Park, Cal., London, Amsterdam, Don Mills, Ontario, Sydney 1977, XVI, 688 S. Biom. J. 1981, 23, 413-414. [CrossRef]

43. Almansouri, M.; Kinet, J.-M.; Lutts, S. Effect of salt and osmotic stresses on germination in durum wheat (Triticum durum Desf.). Plant Soil 2001, 231, 243-254. [CrossRef]

44. Zou, J.; Liu, C.F.; Liu, A.L.; Zou, D.; Chen, X.B. Overexpression of OsHsp17.0 and OsHsp23.7 enhances drought and salt tolerance in rice. J. Plant Physiol. 2012, 169, 628-635. [CrossRef] [PubMed]

45. Scasta, J.D.; Trostle, C.L.; Foster, M.A. Evaluating alfalfa (Medicago sativa L.) cultivars for salt tolerance using laboratory, greenhouse and field methods. J. Agric. Sci. 2012, 4, 90. [CrossRef]

46. Cornacchione, M.V.; Suarez, D.L. Evaluation of alfalfa (Medicago sativa L.) populations' response to salinity stress. Crop Sci. 2017, 57, 137-150. [CrossRef]

47. Farissi, M.; Bouizgaren, A.; Faghire, M.; Bargaz, A.; Ghoulam, C. Agro-physiological responses of Moroccan alfalfa (Medicago sativa L.) populations to salt stress during germination and early seedling stages. Seed Sci. Technol. 2011, 39, 389-401. [CrossRef]

48. Boughalleb, F.; Hajlaoui, H.; Mhamdi, M.; Dendon, M. Possible involvement of organic compounds and the antioxidant defense system in salt tolerance of Medicago arborea (L.). Agric. J. 2011, 6, 353-365. [CrossRef]

49. Sibole, J.V.; Cabot, C.; Poschenrieder, C.; Barcelo, J. Ion allocation in two different salt-tolerant Mediterranean Medicago species. J. Plant Physiol. 2003, 160, 1361-1365. [CrossRef] [PubMed]

50. Galmes, J.; Cifre, J.; Medrano, H.; Flexas, J. Modulation of relative growth rate and its components by water stress in Mediterranean species with different growth forms. Oecologia 2005, 145, 21-31. [CrossRef] [PubMed]

51. Teakle, N.L.; Amtmann, A.; Real, D.; Colmer, T.D. Lotus tenuis tolerates combined salinity and waterlogging: Maintaining $\mathrm{O}_{2}$ transport to roots and expression of an NHX1-like gene contribute to regulation of $\mathrm{Na}^{+}$ transport. Physiol. Plant. 2010, 139, 358-374. [CrossRef] [PubMed]

52. Rocha, P.S.C.F. Plant abiotic stress-related RCI2/PMP3s: Multigenes for multiple roles. Planta 2016, $244,287$. [CrossRef] [PubMed]

53. Sairam, R.K.; Tyagi, A. Physiology and molecular biology of salinity stress tolerance in plants. Curr. Sci. 2004, 86, 407-421.

54. Gharsallah, C.; Fakhfakh, H.; Grubb, D.; Gorsane, F. Effect of salt stress on ion concentration, proline content, antioxidant enzyme activities and gene expression in tomato cultivars. AOB Plants 2016, 8, plw055. [CrossRef] [PubMed]

55. Silva-Ortega, C.O.; Ochoa-Alfaro, A.E.; Reyes-Agüero, J.A.; Aguado-Santacruz, G.A.; Jiménez-Bremont, J.F. Salt stress increases the expression of P5CS gene and induces proline accumulation in cactus pear. Plant Physiol. Biochem. 2008, 46, 82-92. [CrossRef] [PubMed] 
56. Mizoi, J.; Shinozaki, K.; Yamaguchi-Shinozaki, K. AP2/ERF family transcription factors in plant abiotic stress responses. Biochim. Biophys. Acta 2012, 1819, 86-96. [CrossRef] [PubMed]

57. Nakano, T.; Suzuki, K.; Fujimura, T.; Shinshi, H. Genome-wide analysis of the ERF gene family in Arabidopsis and rice. Plant Physiol. 2006, 140, 411-432. [CrossRef] [PubMed]

58. Mizukami, Y.; Fischer, R.L. Plant organ size control: AINTEGUMENTA regulates growth and cell numbers during organogenesis. Proc. Natl. Acad. Sci. USA 2000, 97, 942-947. [CrossRef] [PubMed]

59. Meng, L.S.; Wang, Y.B.; Yao, S.Q.; Liu, A.Z. Arabidopsis AINTEGUMENTA mediates salt tolerance by trans-repressing SCABP8. J. Cell Sci. 2015, 128, 2919-2927. [CrossRef] [PubMed]

60. Sinha, A.K.; Jaggi, M.; Raghuram, B.; Tuteja, N. Mitogen-activated protein kinase signaling in plants under abiotic stress. Plant Signal. Behav. 2011, 6, 196-203. [CrossRef] [PubMed]

61. Kiegerl, S.; Cardinale, F.; Siligan, C.; Gross, A.; Baudouin, E.; Liwosz, A.; Eklof, S.; Till, S.; Bogre, L.; Hirt, H.; et al. SIMKK, a mitogen-activated protein kinase (MAPK) kinase, is a specific activator of the salt stress-induced MAPK, SIMK. Plant Cell 2000, 12, 2247-2258. [CrossRef] [PubMed]

62. Tang, L.L.; Cai, H.; Ji, W.; Luo, X.; Wang, Z.Y.; Wu, J.; Wang, X.D.; Cui, L.; Wang, Y.; Zhu, Y.M.; et al. Overexpression of GsZFP1 enhances salt and drought tolerance in transgenic alfalfa (Medicago sativa L.). Plant Physiol. Biochem. 2013, 71, 22-30. [CrossRef] [PubMed]

63. Chao, Y.; Kang, J.; Sun, Y.; Yang, Q.; Wang, P.; Wu, M.; Li, Y.; Long, R.; Qin, Z. Molecular cloning and characterization of a novel gene encoding zinc finger protein from Medicago sativa L. Mol. Biol. Rep. 2009, 36, 2315. [CrossRef] [PubMed]

64. Kawasaki, S.; Borchert, C.; Deyholos, M.; Wang, H.; Brazille, S.; Kawai, K.; Galbraith, D.; Bohnert, H.J. Gene expression profiles during the initial phase of salt stress in rice. Plant Cell 2001, 13, 889-905. [CrossRef] [PubMed]

65. Lisa, A.L.; Elias, S.; Rahman, M.; Shahid, S.; Iwasaki, T.; Hasan, A.K.M.M.; Kosuge, K.; Fukami, Y.; Seraj, Z. Physiology and gene expression of the rice landrace Horkuch under salt stress. Funct. Plant Biol. 2011, 38, 282-292. [CrossRef]

66. Bojórquez-Quintal, E.; Velarde-Buendía, A.; Ku-González, Á.; Carillo-Pech, M.; Ortega-Camacho, D.; Echevarría-Machado, I.; Pottosin, I.; Martínez-Estévez, M. Mechanisms of salt tolerance in habanero pepper plants (Capsicum chinense Jacq.): Proline accumulation, ions dynamics and sodium root-shoot partition and compartmentation. Front. Plant Sci. 2014, 5, 605. [PubMed]

67. Shabala, S. Learning from halophytes: Physiological basis and strategies to improve abiotic stress tolerance in crops. Ann. Bot. 2013, 112, 1209-1221. [CrossRef] [PubMed] 